https://doi.org/10.24101/logos.2020.79

Gauta 20201014

ALMANTAS SAMALAVIČIUS

Vilniaus Gedimino technikos universitetas, Lietuva

Vilnius Gediminas Technical University, Lithuania

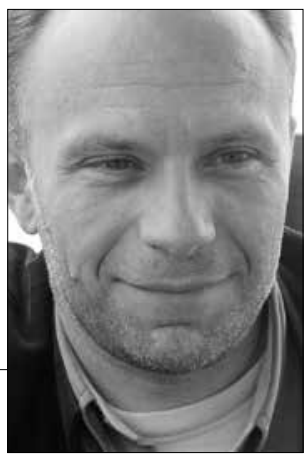

\title{
BIOFILIŠKA ARCHITEKTŪRA: GALIMYBĖS IR TRIKDŽIAI
}

\section{Biophilic Architecture: Possibilities And Grinders}

\begin{abstract}
SUMMARY
The notion and concept of biopphilic architecture is discussed in the article and the author also reconsiders its assumptions asking whether it can become on the global scale a tool for solving the problems of quality of life in cities. The notion of biophilia, introduced several decades ago by socio-biologist Edward O. Wilson, has become an object of interest not only in the architectural academy but also by those architectural designers dissilusioned with promises of vanguard modernist ideology and the ongoing "business as usual". The author attempts to inquire how this concept can make an impact not only on current architectural theory, but also what role it can play in equipping architectural designers with practical tools for reshaping the ailing urban environment. At the same time, the author suggests that it is the "vanguard" ideology of modernism with its dogmatism that resurfaces in globalised Western architectural discourse. Modernism keeps architectural designers from shifting their attitudes towards reshaping the built environment and halts the momentum of biophilic architecture to solve the most acute problems of the built environment.
\end{abstract}

\section{SANTRAUKA}

Straipsnyje svarstoma biofiliškos architektūros koncepcija bei jos atsiradimo prielaidos, susijusios su pastebimai blogèjančia urbanistinio gyvenimo kokybe globaliu mastu. Biofilijos sąvoka, prieš keletą dešimtmečiu aptarta sociobiologo Edwardo O. Wilsono, pastaruoju metu sulaukia vis daugiau atgarsio architektūros ir urbanistikos teoretikų darbuose bei pamažu mėginama pritaikyti ją praktiškai. Mėginama aiškinti, kuo ši sąvoka bei jos pagrindu kuriama koncepcija gali praturtinti ne tik teorinį architektūros diskursą, bet ir pastebimai paveikti architektūrinio bei urbanistinio projektavimo praktiką, kartu svarstant, kodèl joje slypintis potencialas kol kas tebėra menkai išnaudojamas. Straipsnyje teigiama, kad "avangardinio“ 
modernizmo dogmatika, persmelkusi globalizuotą Vakarų architektūros bei urbanistikos diskursą, ir yra pagrindinė kliūtis, užkertanti kelią pasitelkti biofilišką aplinkos projektavimą sprendžiant aktualiausias dirbtinès aplinkos problemas.

\section{IVADAS}

Devynioliktas ir dvidešimtas amžiai buvo sparčios plataus masto urbanizacijos laikotarpis, turëjęs nemenkų pasekmių žmoniu gyvenamosios aplinkos pokyčiams. Nepaisant lūkesčių, pažadintų industrinès ir technologinès revoliucijos, precedento neturintys globalūs masinès urbanizacijos procesai sukèlè galybę prieštaru tiek „,išsivysčiusių“, tiek ir „,besivystančių" moderniujų visuomeniu gyvenime. Pažangos viziją iškèlusi ir suabsoliutinusi architektūrinio bei urbanistinio modernizmo ideologija akivaizdžiai nesugebejo igyvendinti savo pažadų, tad šiandieniniai didmiesčiai toliau kenčia nuo daugybės socialinių negalavimų: didejja socialinè atskirtis, menkai keičiasi mažiausiai pasiturinčiu žmoniu gyvenimo sąlygos, ivvairiausiose pasaulio vietose daugeja ne tik priemiesčio zonu, bet ir lūšnynu, o ką jau kalbèti apie aiškius urbanistinès estetikos nuosmukius. Vadinamosiose „išsivysčiusiose šalyse“ netrūksta urbanistiniu problemų: vyksta sparti miesto kvartalu "getoizacija“, urbanistinės vietovès sparčiai praranda ankstesni savitumą ir tapatumą pasaulio miestai vienodejja, istoriniai miestai pamažu virsta vien vojeristiniam turisto žvilgsniui skirtais reginiais prarasdami ankstesnius miesto kultūros ypatumus. Nemažą dali šiu problemų sukūrè avangardinė modernizmo ideologija, kuri buvo pasišovusi sukurti naują urbanistinio gyvenimo kokybę, tačiau savo užmojų igyvendinti nesugebėjo. Nors pastaruoju metu globa- liu mastu didejja ne tik nepasitenkinimas urbanistinio gyvenimo salygomis, bet siūlomos ivvairios koncepcijos ir strategijos, dažniausiai akcentuojančios tvarumo, darnos, elastingumo poreikị architektūroje bei urbanistikoje, tačiau pokyčiu mastas ir tempas kelia veikiau nusivylimą, nei žadina optimizmą.

Kita vertus, neišvengiamų pokyčiu būtinybę implikuoja akivaizdžiai kintantis architektūros ir urbanistikos diskurso žodynas, kuriame atsiranda ir įsitvirtina naujos sąvokos ir koncepcijos, o kartu su jomis plètojamos ir atitinkamos strategijos, kurios galbūt nulems teigiamus pokyčius ateities architektūroje, statyboje ir miestokūros procesuose. Biofilija ir yra viena tokiu perspektyviu sąvoku, kurią jau spèta konceptualizuoti ir pateikti ne tik jos teorines interpretacijas, bet ir paméginta igyvendinti praktiškai. Deja, Lietuvos akademinëje bei publicistinëje literatūroje, susijusioje su architektūra bei urbanistika, biofiliškos architektūros koncepcija (juo labiau praktika) beveik neminima. Tai rodo pastebimą atotrūkị nuo šiuolaikinio architektūrinio mąstymo perspektyvų, kurị derètų kritiškai įvertinti apmąstant ir suvokiant to atotrūkio priežastis bei (galimas) pasekmes. Tad šiame straipsnyje mėginsime išsiaiškinti šios koncepcijos perspektyvumą sprendžiant dirbtinès aplinkos (t. y. miestų ir jų architektūros) problemas pasitelkus prasmingą ir vilčiu teikiančią architektūrinio bei urbanistinio projektavimo perspektyvą. 


\section{BIOFILIJOS KONCEPCIJA IR DIRBTINĖ APLINKA}

Nors biofilijos sąvoką $1973 \mathrm{~m}$. turbūt pirmasis vienoje savo knygu paminèjo psichologas ir filosofas Erichas Frommas, šio reiškinio koncepciją $1984 \mathrm{~m}$. išsamiau pagrindè ir nusake evoliucinès biologijos srityje dirbantis amerikiečiu mokslininkas Edwardas O. Wilsonas, anot kurio - žmogui ,igimta tendencija susitelkti ties gyvybe ir gyvybe primenančiais procesais" (Wilson 1984: I). Vèlesnejje kolektyvinëje biofilijos reiškinio svarstymui skirtoje mokslo tyrimu bei teorinių svarstymu knygoje Biofilijos hipotezé, ì kurios rengimą ịsitraukè nemažas būrys ịvairiu mokslo sričių atstovų, Wilsonas savo koncepciją ir jos reikšmę paaiškino taip: „Jei biofilija egzistuoja, o, mano manymu, ji egzistuoja, ji yra igimta emocinè žmoniu priklausomybe kitoms gyvoms būtybèms. Igimtumas reiškia paveldejima, tad jis sudaro dali žmogaus prigimties. Biofilija, kaip kiti kompleksiški elgsenos modeliai, yra veikiausiai perduodama pasirengimu išmokti ar priešintis tam tikrų atsakų išmokimui kaip priešybei kitiems. Iš negausių i̇rodymu, susijusių su jos prigimtimi, galima spręsti, kad biofilija nèra vienišas instinktas, o veikiau yra taisykliu išmokimo kompleksas, kuri galima išnarstyti ir analizuoti individualiai" (Wilson \& Kellert 1993: 32). Šiame kolektyviniame veikale tyrinètojas nurode, kad toki daugialypị, kompleksišką reiškini (jo pavadintą biofilija) sąlygojo tai, kad žmogus didžiają dali savo evoliucinio proceso praleido tarp laukinès gamtos ir gyvu organizmu, todèl jo neslopstanti prieraišumą prie gyvybès formu sąlygojo tiek genetika, tiek toje aplinkoje susiformavę kultūriniai ippročiai. Kitaip tariant, žmogus, kaip ir kitos gyvos būtybès, atsirado ir vystėsi supamas bioịvairovès, todèl liko natūraliai su ja susisaistęs. Deja, vèlesniame žmonijos raidos tarpsnyje (mokslininkas šiame kontekste išskiria devynioliktaji ir dvidešimtajj šimtmečius) dèl intensyvios žmonių veiklos drastiškai paspartëję bioịvairovès išnykimo procesai ėmė neišvengiamai ardyti šią prigimtinę priklausomybę ir sąlygojo daugybę žmogaus dvasinę pusiausvyrą trikdančių ir niokojančių emocijų.

Anot Wilsono, civilizacijoje issigalejus technologijoms ir technologiniams procesams, žmonių aplinka iš esmès pakito: žmonès ème gyventi uždarose ir ",reliatyviai steriliose" patalpose, iš gyvenamujju vietu i darbą èmé judèti automobiliais, o didmiesčiu aplinka tapo visiškai nesvetinga gamtai, galutinai atribodama žmones nuo tūkstantmečius juos supusio natūralaus konteksto. Tai negalëjo nepadaryti poveikio asmens emociniam stabilumui. Nors teisybès dèlei tenka pripažinti, kad genas, sąlygojantis biofilijos reiškini, iki šiol nèra nustatytas, tai netrukdo biofilijos hipotezès autoriui ir jo gausèjantiems pasekejams tvirtinti, kad industrinès revoliucijos sąlygota permanentinè kova su gamta, kurią dar labiau paspartino pažangos bei moderniuju technologiju issigalèjimas praejjusiame amžiuje, galutinai atribojo žmogų nuo ji patị sukūrusios natūralios gamtinès aplinkos. Pripažinus ši ilgalaikès simbiozès tarp žmogaus ir gamtos pasaulių praradimą ir jo niokojančias pasekmes, atsirado akstinas pamąstyti, kaip galima būtų atkurti pažeistą pusiausvyrą ir žmo- 
gų vèl „priartinti“ prie nutolusios gamtinès aplinkos. Suprantama, daugelis tokio pobūdžio tyrimų susitelkè i šiuolaikinę dirbtinę aplinka, t. y. ì moderniuosius architektūrinius bei urbanistinius kontekstus. Wilsono kolega, bendradarbis ir bendramintis ekologas Stephenas R. Kellertas, perkèlęs daugialypio biofilijos reiškinio tyrimą i dirbtinę aplinką (architektūros ir urbanistikos sferas) yra pabrèžęs: „Estetinis atsakas veikiausiai atspindi žmogaus intuityvų atpažinimą arba idealo sieki gamtoje: harmonijos, simetrijos ir tvarkos kaip žmogiškos patirties ir elgsenos modelio" (Wilson \& Kellert 1993: 50). Ekologo teigimu, žmogiškos pilnatvès bei savirealizacijos galimybių ir derètų ieškoti žmones supančioje gyvybès ir gyvenimo ịvairovëje. Kiek vèliau kiti mokslininkai èmèsi tyrimų, atskleidusių žmogaus sveikatos priklausomybę nuo ji supančios aplinkos.

\section{GAMTOS, ŽMOGAUS IR ARCHITEKTÜROS SĄVEIKA}

Tyrinėdamas ligonių, gydomų sveikatos priežiūros įstaigose, sveikimo sąlygas, aplinkos psichologas Rogeris Ulrichas $1984 \mathrm{~m}$. padarè anuomet akademinę bendruomenę sukrètusi atradimą: jis nustatè, kad vertinant pacientų išgijimo trukę, komplikacijas po sudètingų operaciju bei pooperaciniu periodu suvartotų nuskausminamųu u vaistų kieki, ligonių rezultatai akivaizdžiai skyrèsi: viena ju grupè sveiko greičiau, komplikaciju patyrè mažiau, nuskausminamuosius vartojo trumpiau, tuo tarpu kita - ilgiau, o ši skirtumą lèmè iki tol niekam nežinomas veiksnys - vaizdas pro ligoninès langa. Tie ligoniai, kurie buvo gydomi palatose, kur vaizdai atsiverdavo tik $i$ kitu gydymo įstaigos kompleksu sienas, arba tie, kurių palatose jokių langų iš viso nebuvo, sveiko gerokai ilgiau ir ju gydymas buvo sudètingesnis nei tų pacientú, kurių palatose buvo galima pro langą grožètis gyvos gamtos vaizdais. Šis atradimas paskatino tyrinėtoją padaryti išvada, kad gamtos vaizdų stebėjimas darè ne tik teigiamą įtaką ligonių sveikimo procesams, bet ir akivaizdžiai sutrumpi- no jų buvimo gydymo įstaigoje laika, tad visuomenei šis atradimas turejo ir ekonominių padarinių (Ulrich 1984: 420-421). Kita vertus, šio tyrimo metu gauti duomenys implikavo, kad estetinè patirtis buvo tiesiogiai susijusi su sveikatos būklès kaita. 1986 m. tolesnis Ulricho tyrimas, atliktas Švedijos ligoninèse, atskleidè, kad gydant psichiatrijos srities pacientus, gamtos vaizdai darè jiems neabejotinai teigiamą poveiki (šis atradimas netrukus buvo panaudotas plečiant pozityvią gydymo praktiką). Kiek vèliau savo išsamioje studijoje „Biofilija, biofobija ir gamtovaizdis“, parašytoje kaip skyrius Wilsono ir Kellerto redaguotai kolektyvinei monografijai, apibendrindamas ankstesnių tyrimų rezultatus, Ulrichas pažymėjo, kad „,teiginys, esą žmonès gali turèti genetikos nulemtą polinki pozityviai sąveikauti su gamta, daugeliui mokslininkų dabar jau atrodo tikètinas. Gamtinè aplinka kūrè kasdienès patirties kontekstą visos žmogaus evoliucijos metu ir buvo esminio pranašumo, taip pat iššūkių bei rizikos šaltinis. Teiginys, kad evoliucija galejo palikti savo žymę mo- 
derniuose žmonèse iš dalies genetiškai sąlygoto reagavimo i gamtą forma, yra mažų mažiausiai tikètinas ir galbūt paaiškès, kad, pavyzdžiui, genetika vaidina savo vaidmeni rūkant cigaretes ar žmogaus asmenybejje. Poreikis praplèsti supratimą apie žmonių reagavimą i gamtą yra nauja mokslinio tyrimo kryptis, kuri gali padèti mums geriau suprasti savo žmogiškuma, atrasti esminius žmogaus isitikinimus, kurie kyla iš gamtinės aplinkos, ir izvertinti praradimus, kylančius iš gamtos niokojimo" (Ulrich 1993: 126). Novatoriški tyrimai, kuriuos atliko žmogaus santykiais su gamtine aplinka besidomintys įvairių sričių mokslininkai, padejo ittvirtinti supratima, kad tam tikro pobūdžio gamtinè geometrija, gamtos formos bei jos reiškinių savybès geba daryti itin dideli poveikį žmonėms, o ligos gydymo (bei pooperaciniu) laikotarpiu daro esminę itaką jų sveikatos būklei ir išgijimo trukmès rodikliams. Beje, apie tai, kad estetiški vaizdai daro teigiamą poveikį žmogaus emocinei būklei, iš tiesų buvo žinoma jau viduramžių laikotarpiu. Olandų kultūros istorikas Johanas Huizinga savo plačiai pagarsejjusioje knygoje Viduramžiu ruduo, skirtoje vėlyvajam viduramžių tarpsniui, yra aprašęs atveji, kai pilies bokšto celejje ikalinto karališko asmens grotuoti langai buvo specialiai ištapyti spalvingais paveikslèliais, kad kalinys uždaroje patalpoje jaustųsi geriau. Dabar tai buvo izrodyta tyrimais.

Tai, kad ne tik realiu gamtos vaizdų, bet ir juos perteikiančių meno vaizdiniu estetinè patirtis daro pozityvų poveiki žmonėms, ypač sergantiems ir atsidūrusiems ligoninès aplinkoje, yra atskleidę ivairių mokslininku, tarp jų ir Ulricho, atlikti tyrimai (Ulrich 1993: 87-88). Ta- čiau kaip yra pastebejjęs mokslininkas, atradimai kelią i viešumą skynèsi ilgai, kadangi šiuos klausimus tyrinėję aplinkos psichologai anuomet sudarè tik labai nedidelę psichologijos specialistų grupę ir šios disciplinos srityje užèmè periferinę pozicija todèl jų tyrimai ilgą laiką nebuvo laikomi prioritetiniais, o tai sąlygojo, kad ju vykdymui nebuvo skiriama adekvati parama. Tačiau nepaisant ivvairių objektyvių ir subjektyvių kliuvinių, Wilsono prieš kelis dešimtmečius iškelta biofilijos hipotezè pastaruoju metu sulaukia vis didesnio įvairių sričių tyrinètojų dèmesio, ypač tų, kurių interesai susiję su architektūra ir dirbtinès aplinkos sfera. Kai kurios pastarojo meto studijos atskleidžia daugybę anksčiau nežinotų duomenų apie tai, koki poveiki žmogaus psichikai ir emocinei būklei daro architektūra ir miesto aplinka (Kellert, Heerwagen, Mador 2008; Sussman \& Hollander 2015). Kai kuriuos sąveikos tarp žmogaus ir jo gyvenamosios urbanistinès aplinkos aspektus esu aptaręs ankstesnėse publikacijose (Samalavičius 2018; Samalavičius 2019).

Plètodami ir toliau grisdami biofilijos hipotezę ižvalgesni tarpdisciplininių sąveikų nesibaidantys architektūros ir urbanistikos tyrinètojai pastaruoju metu jau akcentuoja, kad be didesnių išlygų galima tvirtinti: „Mus biologiškai traukia tam tikra aplinka: estetinès tų vietovių savybės daro stiprinanti poveiki mūsų sveikatai mažindamos îtampa, o būnant lauko aplinkoje, skatinamas didesnis mūsų judrumas. Daugelis studijų parodè, kad biofiliškos savybès akina mus daugiau vaikščioti pėsčiomis ir užsiimti įvairia veikla lauke. Pasivaikščiojimo gamtoje nauda yra dalis bet kurios mums ži- 
nomos žmonių kultūros, tad tai turètų kažką reikšti“ (Mehaffy and Salingaros 2011: 100). Gamtinès aplinkos estetinis poveikis bei žmogaus sveikatingumą potencialiai stiprinantys gamtos ypatumai tai tik vienas iš galimų biofilijos reikšmès supratimo aspektų. Kaip toliau plètodami šią tyrimų problematiką pabrèžia architektūros ir urbanistikos teoretikai Michaelis Mehaffy ir Nikos Salingaros, „kitas aspektas, rodantis biofilijos svarba, yra informacijos perkèlimas ir suvokimas pasitelkiant neurologinius procesus. Mūsų nervų sistema vystėsi reaguodama i išorinius stimulus, tokius kaip informacija, teikiama gamtinès aplinkos. Kad instinktyviai jaučiame savo biologines sąsajas su pasauliu, lemia mentaliniai procesai, susiklostę per šimtus tūkstančių metu, kai gyvename gamtoje" (Mehaffy and Salingaros 2011: 101).

Kellertas yra išskyręs penkias sąlygas, kurios būtinos norint kalbèti apie iš tiesų biofilišką architektūrą, o platesne prasme - ir visą dirbtinę žmogaus aplinką. Pasak tyrinètojo, dirbtinès aplinkos projektavimą galima laikyti biofilišku tik tuo atveju, kai jis tenkina penkias sąlygas: pirma, padeda žmonėms prisitaikyti prie gamtos; antra, kuria pabrèžtinai tvarius santykius su gamta; trečia, reikalauja, kad projekto intervencija būtų susieta su vietos ypatumais; ketvirta, pabrèžia emocini prisirišimą prie gamtos ir aplinkos bei tinkamai ivertina biologija; penkta, ittvirtina „pozityvią ir tvarią sąveiką tarp žmonių ir gamtinès aplinkos. Biofiliškos architektūros privalumas atsiskleidžia architektūrinès patirties metu, žmogui netarpiškai sąveikaujant su pastatais ir platesniu urbanistiniu kontekstu. Tyrinètojas skirsto architek- tūros patirtis į dvi rūšis: tiesioginę ir netiesioginę. I tiesioginę įeina vandens, oro, augalų, gyvūnų, natūralių kraštovaizdžių patyrimas, o netiesioginę sudaro gamtos vaizdai, medžiagos, spalvos, kultūrinis prieraišumas prie vietų, natūralaus apšvietimo ir gryno oro stimuliavimas pasitelkiant architektūros priemones, naudojimasis gamta, informacijos turtingumas, gamtinè geometrija bei biomimikrija (Wilson \& Kellert 2008).

Tačiau svarbu suvokti, kad biofiliška architektūra nereiškia vien paprasčiausio gamtos elementų, pavyzdžiui, augmenijos, medžių ar vandens telkinių perkèlimą i architektūrinę ir / ar urbanistinę aplinka, juoba kad tokie siekiai dažniausiai tèra noras papildyti ją dekoratyviais elementais ar suteikti jai paviršutiniško estetiškumo. Deja, neretai projektuojantys architektai issivaizduoja, kad tokių elementų kaip sienų ar stogo apželdinimas, vandens baseinų ar fontanų įrengimas bei augalų estetiškas integravimas i architektūrinę aplinką ir yra biofiliškas projektavimas, nes esą žmogaus aplinkoje atsiranda daugiau natūralios augmenijos, kuria jis gali gèrètis ir mėgautis. Nors gamtos elementų buvimas dirbtinèje aplinkoje yra savaime svarbus, tačiau tai nereiškia, kad taip suprojektuota / dekoruota aplinka igauna būtinų biofiliškumo požymių. Dar didesnè klaida daroma vaizduojantis, kad architektūra patiriama ir suvokiama vien žvilgsniu.

Biofiliška architektūrinė aplinka privalo būti gyvybinga, o architektams būtina suvokti, kad žmonès patiria dirbtinę aplinką ne tik ir ne tiek kaip vaizdus, t. y. ne vien rega, bet ir lytejimu, klausa ir kitais pojūčiais. Kitaip tariant, patirdami architektūrą ir gamta, žmonès išgyvena 
pojūčius, kuriuos sukelia šviesa, formos, medžiagos, spalvos ir daugybė kitų gamtoje esančių elementų. Mehaffy ir Salingaros primena, kad gamta niekuomet nekartoja savęs pasitelkusi identiškus modelius ar mechanišką geometrija, ir „,nors monotoniškas pasikartojimas buvo pagrindinè architektūros tipologija pasibaigus Antrajam pasauliniam karui - ji yra antibiofiliška" (Mehaffy \& Salingaros 2011: 105). Nors yra tam tikrų viltingu, jau igyvendintų projektų išimčių, tačiau kol kas urbanistinė aplinka, švelniai tariant, nèra draugiška gamtai, kadangi antibiofilišką architektūrą ir urbanistiką globaliu mastu formavo tiek modernistinè ideologija, akcentavusi technologinę pažangą, mobilumą, masinę aplinkos homogenizacija, tiek modernioji statybos industrija, siekusi kuo didesnio efektyvumo ir finansinio pelningumo ir šiems tikslams panaudojusi architektūros ir miesto teoriją. Nenuostabu, kad šių ideologijų ir tendencijų mišinys sukūrè toksišką gyvenamąją aplinką, kurią pakeisti iš esmès būtina, suprantama, jei iš tiesų norima, kad ji keltų kuo mažiau itampos, depresijos ir kitų negatyvių žmogaus dvasinę pusiausvyrą destabilizuojančių emocijų. Tai reiškia, kad būtina atsisakyti praëjusiame amžiuje îsigalejusios estetinès ir ideologinès dirbtinès aplinkos paradigmos, kadangi joje dominavusią architektūrą galima pagristai laikyti antbiofiliška (Salingaros 2013). Tarp ryškiausių tokios aplinkos savybių galima paminèti: brutalistines (sintetines) medžiagas (pavyzdžiui, nesaikingai statybose naudojamą betoną), kurioms būdingi negyvybingi ir neišraiškingi paviršiai, tiek Šiaurès ir Pietų pusrutulių miestuose beatodairiškai naudojamą stiklą, dèl kurio statiniai paverčiami ištisiniais tamsinto stiklo ekranais, gamtos elementų išstūmimą iš urbanistinès aplinkos arba miestuose esančių vandens telkinių (upių, ežeru, tvenkinių ir kt.) bei žaliosios masès (miškų, kalvų, medžių, krūmų) naikinimą arba panaudojimą vien dekoratyvumo tikslais.

Tačiau ne mažiau svarbu įvertinti tai, kad modernioji estetika iš esmės nuskurdino architektūrinès raiškos priemonių arsenalą. Architektūroje įsivyravo agresyvus formų ir paviršiu minimalizmas, tiesios linijos ir statūs kampai, kuriuos, beje, dar trečiajame praejusio amžiaus dešimtmetyje programiškai išaukštino Le Corbusier, pasmerkdamas istorini miestų paveldą ir ypač viduramžių urbanistikos laimèjimus (Le Corbusier 1947). Toks požiūris įtvirtino urbanistinès megalomanijos forma, kuri ìsigalejo globaliu mastu, nors pačiam ideologui pavyko igyvendinti tik labai nedidelę dali savo urbanistinių projektų (Samalavičius 2013: 46-56). Kartu su modernistine architektūros ir miestokūros ideologija įsigalejo ne tik tiesios linijos ir statūs kampai, bet ir primityvios geometrinès statinių formos - kubai, cilindrai ir pan. (Mehaffy \& Salingaros 2015: 39-44).

Modernioji architektūros teorija susižavejjo abstrakčiomis ir formaliomis kartezietiškomis erdvès sampratomis, vieta buvo sutapatinta su erdve, nors šios sąvokos nėra tapačios (Robert 2001: 102104). Pasitelkus abstrakcijas, analogiškai imta intepretuoti miestą. Modernioji architektūros ir urbanistikos teorija, igavusi ideologinès doktrinos pobūdi, nebekreipe jokio dmésio ì psichologinius (juslinius bei emocinius) žmogaus san- 
tykius su gamtine ir dirbtine aplinka, kadangi ja, laikantis Le Corbusier dogmu, imta intepretuoti mechanistinėmis kategorijomis - kaip „gyvenimui skirtą mašiną". İsigalèjęs industrinis statybos pobūdis esmingai pakeitè urbanistinę aplinka, o modernieji architektai su dideliu ūpu èmèsi demiurgų vaidmens, esą geriau už žmones suprantantys ir žinantys, kokios gyvenamosios aplinkos jiems reikia, tad jiems globaliu mastu buvo primestas urbanistinès pažangos vaizdinys. Visi šie veiksniai sukūrè globalų reiškinį, kurį Lewisas Mumfordas prieš kelias dešimtis metų ižvalgiai pavadino „antimiestu” (Mumford 1960).

\section{KOMPLEKSIŠKUMAS IR BIOFILIŠKA ARCHITEKTÜRA}

Kaip jau buvo pažymėta anksčiau, biofiliška architektūra nereiškia vien mechaniško gamtos elementų perkèlimo i architektūrinius interjerus ar urbanistinę aplinką. Turint galvoje, kad žmogus yra gamtos dalis ir tūkstantmečius vystèsi gamtinejje aplinkoje, galima daryti pagrįstą prielaida, kad žmogaus jautrumas natūraliai šviesai, grynam orui, vandeniui ir kitiems gamtos aspektams nèra išnykęs. Netgi atvirkščiai, jis slypi giliai žmogaus sąmoneje. Todèl šviesos, vandens ir kitų gamtos elementų šaltinius galima ir būtina perkelti i žmogaus gyvenamąją aplinką tam, kad ją praturtintų natūralių pojūčių. Architektūrinė aplinka, kaip ir gamtinè, neturètų būti skirta tenkinti kurị nors vieną iš pojūčių, bet daryti holistini poveikị iš karto keliems pojūčiams.

Kita vertus, duomenys, kuriais šiandieną disponuojame, leidžia suvokti, kad žmonès statė ir stato pastatus ir miestus anaiptol ne vien dèl utilitarių priežasčiu (priešingu atveju kiltų klausimas, kodèl architektūra turètų būti estetiška), tad statinių formos, raiškos, estetikos neįmanoma redukuoti iki dekoratyvių elementú. Tiek klasikinè, tiek tradicinè / namudinė architektūra pasižymėjo tam tikromis savybėmis (tarp jų itin svarbus buvo pastato ir vietos santykis), i kurias nustota kreipti dèmesi îsigalejus moderniesiems industriniams statybos ir projektavimo būdams.

Gamtinès formos pasižymi įvairove ir kompleksiškumu, o tokie patys bruožai būdingi kokybiškai architektūrai, pasižyminčiai biofiliškomis savybėmis. Kellertas yra pastebėjęs, kad fraktalinès formos yra itin būdingos biofiliškai architektūrai (Kelltert 2008), o Andrew Cromptonas ir daugelis kitų autorių yra atkreipęs dèmesị, kad izvairiausius fraktalų variantus galima aptikti per visą architektūros istorijos raidą netgi skirtingose kultūrose (Crompton 2002). Kiti tyrinètojai nurodo, kad fraktalus primenančios architektūrinės bei dekoratyvinės formos ir struktūros itin būdingos senajai induizmo, baroko bei islamiškajai architektūrai (Ramzy 2015: 47). Kita vertus, jau anksčiau kai kurie autoriai yra išsiaiškinę, kad fraktalinio pobūdžio kompozicijose aiškiai pastebima dydžių ir centrų hierarchija (Salingaros \& Masden 2008). Savo pažiūromis biofiliškos architektūros koncepcijai itin artimas Christopheris Alexanderis yra išsiaiškinęs, kad net penkiolika jo išskirtų centrams būdingų savybių padeda sukurti visumos įspūdi (tarp jų tyrinèto- 
jas nurodo tokius aspektus, kaip dydžiu hierarchija, aiškias ribas, vietinę simetriją, kontrastinguma, aidejimą ir t. t.), o būtent tokios savybès yra būdingos ir gamtos sandaroje aptinkamiems fraktalams (Alexander 2002). Tad fraktališką architektūrą galima laikyti viena iš biofiliškos dirbtinès aplinkos apraiškų. Jos principai minimi ir tarp eksperimentiniais tyrimais gristų keturiolikos modelių, kuriuos akinama taikyti architektūroje (Browning, Ryan \& Clancy 2014).

Kai kurie autoriai, pasitelkę biofiliškos architektūros koncepcija, istoriniams islamo architektūros pavyzdžiams tirti pateike patikimu irodymu, kad tokios savybès (pavyzdžiui, fraktališkumas) yra būdingos islamiškosios medresès (tradicinès religinio mokymo istaigos) erdvinei ir architektūrinei sandarai (Abdelaal \& Soebarto 2018). N. S. Ramzy tyrimai rodo, kad geriausiuose islamo architektūros pavyzdžiuose galim aptikti tokiu biofiliškumo elementų kaip fraktalai, universalus mastelis, kvazikristališki modeliai (pavyzdžiui, Kordobos mečetès bei Alhambros rūmų struktūroje ir puošyboje), o gotikos bei baroko architektūroje - fraktalus ir jungiamają geometriją / hierarchiją (Ramzy 2015: 46-52).

Kai kurie ligoninių aplinką tyrinejjantys autoriai yra atkreipę dèmesi, kad gydymo ịstaigoms itin reikalinga "dialogiška, priimtina, suvokiama ir estetiškai patraukli bei atpalaiduojanti aplinka", suteikianti pasitikejjimo žmonèms, kurie priversti joje praleisti tam tikrą laiką (Totarforti 2018: 5). Tokios paskirties pastatams itin reikalinga biofiliškos architektūros intervencija. Kai kurie autoriai pabrěžia, kad tokio pobūdžio aplinka turètu būti kuriama ir ten, kur rengiami būsimieji architektai (Kayihan, Guney \& Unal 2017). Tad šioje srityje veriasi platūs tolesnio tyrimo ir tyrimu pritaikymo projektavimui horizontai.

\section{IŠVADOS}

Šiuo metu biofiliškos architektūros ir urbanistinès aplinkos sampratos teisètumas nebekelia jokiu abejoniu, o gamtos, jos meninių vaizdinių bei gamtinių struktūru panaudojimo dirbtinèje aplinkoje svarba ir nauda yra iqrodyta ir dokumentuota gausybëje šios srities tyrimu, todèl biofiliškos architektūros koncepciją galima laikyti visiškai pagrista. Tačiau labai svarbu, kad tokios architektūros (ir platesne prasme urbanistinès aplinkos) samprata nebūtų suvokiama paviršutiniškai ir redukuojama iki gamtos elementu ar meninėmis priemonėmis perteiktu gamtos vaizdiniu vaidmens panaudojimo dirbtinèje aplinkoje. Daugelio šios srities tyrimų analizė leidžia tvirtinti, kad gamtos sąveika su žmogumi pasireiškia gamtinių struktūrų esmès perkẻlimu į dirbtinę (architektūrinę ir urbanistinę) aplinką pasitekus architektūros meninès raiškos priemones. Šiuo metu yra sukaupta pakankamai duomenu, kuriais remiantis galima būtų kurti iš tiesų biofilišką architektūrą išsivaduojant iš praejusiame amžiuje dominavusios architektūros bei urbanistikos paradigmos. Tokios aplinkos projektavimui galètu pagelbèti ir naujas požiūris į klasikinę ir tradicinę architektūra, kuri, kaip rodo daugelis ty- 
rimų, pasižymi biofiliškomis savybèmis. Tradicinès architektūros estetikos bei statybos technologiju atgaivinimas galètų būti vienas iš žingsnių žengiant šia kryptimi. Tačiau nè kiek neabejotina, kad pra- èjusio amžiaus architektūrinès ideologijos įtvirtinta mąstymo paradigma tebèra didžiulis kliuvinys norint pereiti nuo biofiliškos architektūros koncepcijos iki jos pritaikymo praktikoje.

\section{Literatūra}

Abdelalaal, Mohamed S., Soebarto, Veronica. 2018. History Matters: The Origins of Biophilic Design of Innovative Learning Spaces in Traditional Architecture, Archnet-IJAR: International Journal of Architectural Research, Vol. 12, isue 3: 108-127.

Alexander, Christopher. 2002. The Nature of Order. Book I. Berkeley: The Center for Environmental Structure.

Browning, W. D., Ryan, C.O. Clancy, J.O. 2014. 14 Patterns of Biophilic Design. New York: Terrapin Bright Green.

Crompton, Andrew. 2002. Fractals and the Picturesque. Environment and Planning B: Planning and Design, No 29: 451-459.

Kayihan, Kutlu Senic, Guney, Sedef Ozcelnik, Sorusu Olarak. 2017. Biphilia as the Main Design Question in Architectural design Studio Teaching, Megaron, 2018, 13 (1), 12.

Kellert, Stephen R, Heerwagen Judith, Mador Martin, editors. 2008. Biophilic Design: The Theory, Science and Practice of Bringing Buildings to Life. Hoboken, NJ: John Wiley and Sons.

Le Corbusier. 1947. The City of To-morrow and Its Planning. London: Architectural Press.

Mehaffy, Michael and Salingaros, Nikos. 2011. Biopphilia. Salingaros, Nikos. Unified Architectural Theory: Form, Language, Complexity. Portland: Sustasis Press, 2013.

Mehaffy, Michael W., Salingaros, Nikos. 2015. Design for a Living Planet: Settlements, Science and the Human Future. Portland: Sustasis Press.

Mehaffy, Michael W. 2017. Cities Alive: Jane Jacobs, Christopher Alexander and the Roots of the New Urban Renaissance. Portland: Sustasis Press.

Mumford, Lewis. 1961. The City in History. Harcourt, Brace Jovanovich.

Ramzy, Shafik Nelly. 2015. Biophilic qualities of historical architecture: In quest of the timeless terminologies of 'ife' in architectural expression, Sustainable Cities and Society 15: 42-56.

Robert, Jean. 2001 (2018). Place in the Space Age, International Journal of Illich Studies, Vol 6, No 1.

Salingaros, Nikos. 2013. Unified Architectural Theory: Form, Language, Complexity. Portland: Sustasis Press.

Samalavičius, Almantas. 2013. Miestas ir protas. Vilnius: Technika.

Samalavičius, Almantas. 2018. Beyond sustainability: reconsidering the healing qualities of the built environment, IOP Conference Series Earth and Environmental Science, 2013 (1): 012001.

Samalavičius, Almantas. 2019. Architektūra ir aplinkos kognityviniai aspektai, Logos 99: 156-165.

Sussman, Ann, Hollander, Justin B. 2015. Cognitive Architecture: Designing fro How We Respond to the Built Environment.

Totarforti, Simona. 2018. Applying the benefits of biophilic theory to hospital design, City, Territory and Architecture 5: 1.

Ulrich, Roger S. 1984 View from the window may influence recovery from surgery, Science, 224: 420-421.

Ulrich, Roger. 1993. Biophilia, Biophobia and Natural Landscapes. Stephen R.Kellert, Edward O. Wilson, editors. The Biophilia Hypothesis. Washington D.C. Island Press.

Wilson, Edward O. 1984. Biophilia. Cambridge, MA.: Harvard University Press.

Wilson, Edward, Kellert, Stephen R. editors. 1993. The Biophilia Hypothesis. Washington, D.C.: Island Press. 